\title{
Diversification of Carbazoles by LiCl-mediated Catalytic CuI Reaction
}

\author{
Joong Hyun Cho, Young-Sil Ryu, Se Hwan Oh, Jae Kwan Kwon, and Eul Kgun Yum* \\ Department of Chemistry, Chungnam National University, Yusung, Daejon 305-764, Korea. *E-mail: ekyum@cnu.ac.kr \\ Received February 24, 2011, Accepted May 16, 2011
}

Key Words : Carbazole, $N$-Arylation, $\mathrm{CuI}, \mathrm{LiCl}$, Diversification

\section{Introduction}

Natural carbazole moieties show various interesting biological activities, such as antibacterial, antiinflammatory, protein kinase inhibitory, and antitumor effects. ${ }^{1,2}$ Recently, synthetic carbazoles and derivatives have been widely used as functional building blocks for optoelectronic applications, due to their specific optical and electrochemical properties. ${ }^{3}$ Organometallic complexes of carbazole have been reported as potential luminescent materials for use in organic lightemitting devices (OLEDs). ${ }^{4}$ The carbazole moiety can be readily functionalized or covalently linked to other molecules, and numerous ways are known for enhancing its conjugated electron system. Specifically, the 2,7- and 3,6linking of carbazole molecules with heterocycles or diarylamine can produce useful organic materials for photovoltaic devices, white light-emitting diodes, and LEDs. ${ }^{5}$ Additionally, polymeric carbazole derivatives have attracted interest for use in solid-state dye-sensitized solar cells. ${ }^{6}$

Although the diverse activities of carbazoles have made them important moieties for material science, $\mathrm{N}$-arylated carbazoles are typically prepared using the Ullmann-type C$\mathrm{N}$ coupling reaction, which requires stoichiometric amounts of copper, harsh conditions, long reaction times, and strong base. ${ }^{4 \mathrm{~d}, 5 \mathrm{~b}, 7}$ Several recent reports have described $N$-arylation of carbazole by catalytic $\mathrm{Cu}$-mediated reaction, but the paper reported only one or several examples of $\mathrm{N}$-arylated carbazoles with organic ligands, such as pyridine-containing 1,3diketone, 1,10-phenanthroline, 9-azajulollidine, increasing cost and resulting in isolation problems. ${ }^{7,8}$ As part of our continuing organometallic research regarding heterocycles, such as indoles, ${ }^{9}$ azaindoles, ${ }^{10}$ and quinolines, ${ }^{11}$ here we describe $N$-arylation of carbazoles by a LiCl-mediated catalytic $\mathrm{CuI}$ reaction and palladium-catalyzed coupling reaction for $\mathrm{N}$-arylated bromocarbazole for the preparation of useful OLED materials.

\section{Results and Discussion}

The starting materials 2-bromo, 2,7-dibromo, and 3,6dibromo carbazole were prepared as described in the literature (Scheme 1). ${ }^{12,13}$ 2-Phenyl carbazole was also prepared from 2-bromocarbazole with phenylboronic acid by palladium-catalyzed Suzuki reaction.

First, we examined $\mathrm{N}$-arylation of carbazole with various aryl halides under our previously reported LiCl-mediated CuI catalytic $N$-arylation conditions for azaindoles. ${ }^{10 f}$ The results showed that optimum conditions for $\mathrm{N}$-arylation of carbazole were 1 equiv $\mathrm{LiCl}, 1$ equiv $\mathrm{Cs}_{2} \mathrm{CO}_{3}, 10 \mathrm{~mol} \% \mathrm{CuI}$, and DMF at $150{ }^{\circ} \mathrm{C}$ for $48 \mathrm{~h}$. The results are summarized in Table 1 . The $\mathrm{N}$-arylation of carbazoles was examined using various aryl iodides or bromides under optimum reaction conditions to diversify $\mathrm{N}$-arylated carbazole. The reaction using substituted iodobenzene provided good-to-excellent yields of $N$-arylated-carbazole (entries 1-4). In particular, the reaction using 1-bromo-4-iodo benzene provided $N$-substituted 4-bromophenyl carbazole with excellent selectivity for the iodo substituent (entry 2).

Additionally, reactions using heteroarylbromides, such as pyridine and thiazole, provided $N$-heteroarylated carbazole in good-to-reasonable yields (entries 5-7). The results showed that reactions using nitrogen-containing heterocycles had the same reactivity with the benzene ring, but the reaction using thiazole provided lower yields of desired product with longer reaction times. The reaction conditions were applied to diversification of substituted-carbazole under substituted aryliodides (entries 10-14). $\mathrm{N}$-Arylation of 2,7- and 3,6dibromocarbazole were also examined with aryliodo compounds. The reactions provided good yields of $\mathrm{N}$ arylated dibromocarbazoles with good-to-excellent yields. However, $N$-arylation of dibromocarbazole with arylbromide provided low yields of desired product, due to unselective $\mathrm{Cu}$ catalyst reactivity for arylbromide and bromocarbazole.
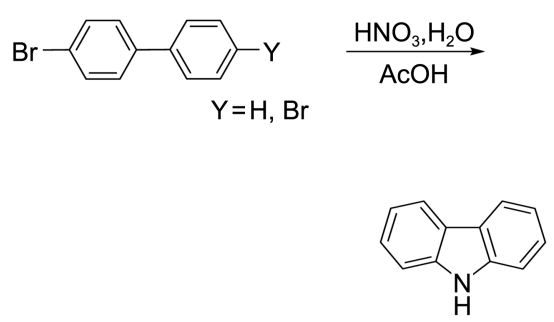

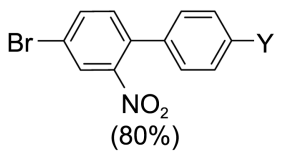

$\underset{\mathrm{CH}_{2} \mathrm{Cl}_{2}}{\stackrel{\mathrm{NBS}, \mathrm{SiO}_{2}}{\longrightarrow}}$
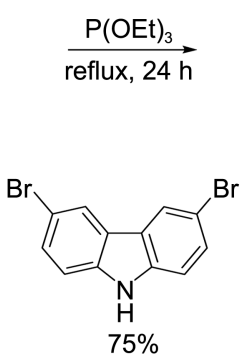

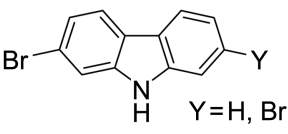

$\mathrm{Y}=\mathrm{H} 80 \%$

$\mathrm{Y}=\mathrm{Br} 71 \%$ 
Table 1. $N$-Arylation of carbazole with arylhalides

\begin{tabular}{|c|c|c|c|c|c|}
\hline Entry $^{a}$ & $R_{1}$ & $R_{2}$ & $\mathrm{X}-\mathrm{Ar}$ & Product & $\begin{array}{c}\text { Isolated } \\
\text { yield }\end{array}$ \\
\hline 1 & $\mathrm{H}$ & $\mathrm{H}$ & & $2 \mathbf{a}$ & 80 \\
\hline 2 & $\mathrm{H}$ & $\mathrm{H}$ & $\mathrm{Br}$ & $2 b$ & 85 \\
\hline 3 & $\mathrm{H}$ & $\mathrm{H}$ & U & $2 c$ & 62 \\
\hline 4 & $\mathrm{H}$ & $\mathrm{H}$ & & 2d & 50 \\
\hline 5 & $\mathrm{H}$ & $\mathrm{H}$ & & $2 \mathrm{e}$ & 74 \\
\hline 6 & $\mathrm{H}$ & $\mathrm{H}$ & & $2 f$ & 70 \\
\hline 7 & $\mathrm{H}$ & $\mathrm{H}$ & & $2 \mathrm{~g}$ & 40 \\
\hline 8 & 2-Ph & $\mathrm{H}$ & & $2 h$ & 78 \\
\hline 9 & $2-\mathrm{Ph}$ & $\mathrm{H}$ & $\mathrm{OBn}$ & $2 \mathrm{i}$ & 62 \\
\hline 10 & $2-\mathrm{Br}$ & $\mathrm{H}$ & & $2 \mathbf{j}$ & 85 \\
\hline 11 & $3-\mathrm{Br}$ & $6-\mathrm{Br}$ & & $2 k$ & 70 \\
\hline 12 & $3-\mathrm{Br}$ & $6-\mathrm{Br}$ & $-\mathrm{CO}_{2} \mathrm{C}$ & 21 & 61 \\
\hline 13 & $2-\mathrm{Br}$ & 7-Br & & $2 m$ & 70 \\
\hline 14 & $2-\mathrm{Br}$ & 7-Br & $-\mathrm{NH}_{2}$ & $2 n$ & 81 \\
\hline
\end{tabular}

${ }^{a}$ All reactions were run on $1.0 \mathrm{mmol}$ scale in $5 \mathrm{~mL}$ of DMF with $10 \mathrm{~mL}$ vial.

For the efficient formation of OLED devices, the decreased device-operation voltage will result in increase power efficiency due to the more effective injection and transport of charges with appropriate combination of host and dopant. ${ }^{14}$ Carbazole and polyarylamine are now widely used as hole transport materials in multilayer organic light emitting diodes due to their electron-donating capabilities. ${ }^{15}$ The polyamine derivatives have high triplet energy and are capable of functioning as host materials in highly efficient blue, green, or red electrophosphorescent devices. We examined the synthesis of 9,9'-diphenyl-4,4-diyl-bis-carbazole (CBP) and $N 4, N 4$ '-di(naphthalen-2-yl)- $N, N 4$ '-diphenyl-4,4'diamine (NPB), well-known host materials for OLED devices. The results showed that CBP and NPB could be synthesized in excellent yields using our $N$-arylation method (Scheme 2).

The most efficient OLED devices reported to date have been multilayer structures with heavy metal phosphorescent emitters, in which the hole transporting layer (HTL), electroluminescent layer (EL), and electron transporting layer (ETL) are sandwiched between two electrodes. ${ }^{14}$ High-vacuum vapor deposition of small molecules or solution processing of polymer macromolecules is usually carried out in OLED device fabrication. ${ }^{15}$ Although fabrication of devices from solution using macromolecules is attractive, one particular requirement for the deposition of multiple layer is that each deposited layer be resistant to the solvent used to deposit subsequent layers. We examined Suzuki coupling of carbazole with arylboronic acid and sequential Wittig reaction (Scheme 3) to prepare thermally cross-linkable hole transporting macromolecules, which can be processed in solution by spin casting or ink jet printing and then transformed into an insoluble film by light or heat treatment. The prepared carbazole-containing monomer could be copolymerized with vinylic benzocyclobutene (BCB) by radical polymerization. ${ }^{16}$ The intermediate would be a precursor material to form thermally cross-linkable hole-transporting macromolecules for solution processing of multilayer OLEDs.

\section{Conclusions}

Simple and efficient $N$-arylation of carbazoles has been achieved by catalytic $\mathrm{CuI}$ reaction without any organic ligand. Although the required long reaction time for the $\mathrm{N}$ arylation of carbazole, the $N$-arylation of halocarbazoles is promising results for diversification of the carbazole moiety. The facile variation of arylhalide and carbazole moieties is very important merits for diversification to biological and OLED materials science. We will further examine the
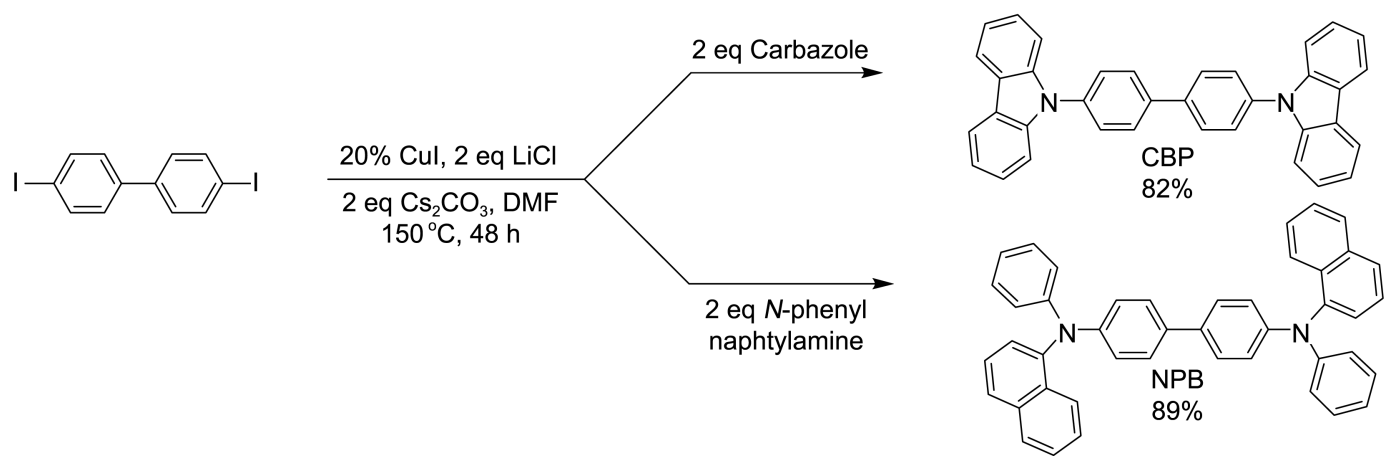
<smiles>Brc1ccc(N(c2ccc(Br)cc2)c2ccc(Br)cc2)cc1</smiles>

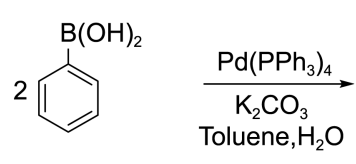
$\mathrm{Br}$<smiles>OB(O)c1ccc(N(c2ccc(-c3ccccc3)cc2)c2ccc(-c3ccccc3)cc2)cc1</smiles>

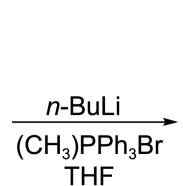

(3d)<smiles>Brc1ccc(N(c2ccc(-c3ccccc3)cc2)c2ccc(-c3ccccc3)cc2)cc1</smiles>
$51 \%$

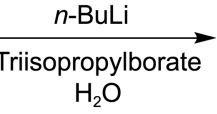
$\mathrm{H}_{2} \mathrm{O}$<smiles>O=Cc1ccc2c(c1)c1ccc(-c3ccc(N(c4ccc(-c5ccccc5)cc4)c4ccc(-c5ccccc5)cc4)cc3)cc1n2-c1ccccc1</smiles><smiles>C=C(C)N(c1ccc(-c2ccccc2)cc1)c1ccc(-c2ccc3c4cc(CC)ccc4n(-c4ccccc4)c3c2)cc1</smiles>
$80 \%$

Scheme 3

synthesized $N$-arylated bromocarbazole intermediates for possible applications in material science.

\section{Experimental Section}

Instrumentation and Analysis. All ${ }^{1} \mathrm{H}$ - and ${ }^{13} \mathrm{C} \mathrm{NMR}$ spectra were recorded on a Jeol $400 \mathrm{MHz}$ spectrometer. Chemical shifts are given as value with reference to tetramethylsilane (TMS) as an internal standard. The GC-MS spectra were obtained on a Shimadzu QP 1000 GC-MS. Products were purified by flash chromatography on 230-400 mesh ASTM 60 silicagel. All of base and $\mathrm{Cu}$ species were purchased from Aldrich Chemical Co. The other chemicals were used directly obtained from commercial sources unless otherwise noted.

General Experimental Procedure for $\boldsymbol{N}$-arylation of Carbazole. $9 H$-Carbazole $(1.0 \mathrm{mmol}), \mathrm{Cs}_{2} \mathrm{CO}_{3}(1.0 \mathrm{mmol})$, iodobenzene (1.1 mmol), CuI (0.1 mmol), and DMF (5 mL) were added in $10 \mathrm{~mL}$ vial with screw cap. The vial was sealed and stirred at $150{ }^{\circ} \mathrm{C}$ in oil bath. After heating the reaction mixture at $150{ }^{\circ} \mathrm{C}$ for $48 \mathrm{~h}$, the reaction mixture was diluted with saturated aqueous ammonium chloride. The product was extracted with ethyl acetate. The ethyl acetate layer was dried over anhydrous magnesium sulfate, filtered, and concentrated. The product was purified by silica gel column chromatography using hexane: ethyl acetate solvent. $N$-Phenyl-carbazole (2a) ${ }^{17}$ was obtained in $80 \%$ yield as a white solid. mp 86-87 ${ }^{\circ} \mathrm{C}$; ${ }^{1} \mathrm{H}$ NMR $\left(400 \mathrm{MHz}, \mathrm{CDCl}_{3}\right) \delta$ $8.18(\mathrm{~d}, 2 \mathrm{H}, J=7.6 \mathrm{~Hz}), 7.61(\mathrm{~m}, 4 \mathrm{H}), 7.50(\mathrm{t}, 1 \mathrm{H}), 7.44(\mathrm{~d}$, $4 \mathrm{H}, J=7.6 \mathrm{~Hz}), 7.32(\mathrm{~m}, 2 \mathrm{H}) ;{ }^{13} \mathrm{C} \mathrm{NMR}\left(100 \mathrm{MHz}, \mathrm{CDCl}_{3}\right)$ $\delta$ 107.6, 104.5, 96.6, 94.2, 93.9, 92.7, 90.1, 87.0, 86.6, 76.5; $\mathrm{Ms}$ ( $\mathrm{m} / \mathrm{z}$, relative intensity): $243\left(\mathrm{M}^{+}, 100\right), 140$ (11), 120 (16).

The Compounds (2b-2n) ${ }^{18}$ were Prepared with General Experimental Procedures.

Tris(4-bromophenyl)amine (3a): Triphenylamine (5 g, $20 \mathrm{mmol}$ ) was dissolved in $30 \mathrm{~mL}$ of chloroform with 50 mL-3-neck round bottom flask. Bromine $(1.6 \mathrm{~mL}, 70 \mathrm{mmol})$ was slowly added to the reaction mixture at $0^{\circ} \mathrm{C}$. The reaction mixture was stirred for $2 \mathrm{~h}$ at $0{ }^{\circ} \mathrm{C}$. The product was extracted with ethyl acetate - water. The ethyl acetate layer was dried with $\mathrm{MgSO}_{4}$, filtered, and concentrated. The product $(8 \mathrm{~g}, 83 \%)$ was obtained by recrystalization with 300 mL of water:ethanol = 1:1. mp 140-142 ${ }^{\circ} \mathrm{C} ;{ }^{1} \mathrm{H} \mathrm{NMR}(400 \mathrm{MHz}$, $\left.\mathrm{CDCl}_{3}\right) \delta 6.95(\mathrm{~d}, 6 \mathrm{H}, J=12 \mathrm{~Hz}), 6.91(\mathrm{~d}, 6 \mathrm{H}, J=12 \mathrm{~Hz})$.

$\mathrm{N}$-(Biphenyl-4-yl)- $\mathrm{N}$-(4-bromophenyl) biphenyl-4-amine (3b): Tris (4-bromophenyl)amine (1 g, $2.1 \mathrm{mmol})$, phenylboronicacid (550 mg, $4.56 \mathrm{mmol}), \mathrm{Pd}\left(\mathrm{Ph}_{3}\right)_{4}(97 \mathrm{mg}, 0.084$ mmol), $\mathrm{K}_{2} \mathrm{CO}_{3}(1.2 \mathrm{~g}, 8.4 \mathrm{mmol})$ was dissolved at $12 \mathrm{~mL}$ of mixed solvent (toluene:THF: $\mathrm{H}_{2} \mathrm{O}=5: 5: 1$ ) in pressure bottle. The reaction mixture was stirred at $80{ }^{\circ} \mathrm{C}$ for $8 \mathrm{~h}$. The product was extracted with ethyl acetate-water. The ethyl acetate layer was dried with $\mathrm{MgSO}_{4}$, filtered, and concentrated. The product $(520 \mathrm{mg}, 51 \%)$ was obtained as white solid by column chromatography with hexane:MC $=20: 1$. mp 172-174 ${ }^{\circ} \mathrm{C} ;{ }^{1} \mathrm{H}$ NMR $\left(400 \mathrm{MHz}, \mathrm{CDCl}_{3}\right) \delta 7.56(\mathrm{~d}, 4 \mathrm{H}$, $J=8.8 \mathrm{~Hz}), 7.47$ (d, 4H, $J=8.8 \mathrm{~Hz}), 7.35(\mathrm{~m}, 8 \mathrm{H}), 7.16$ (d, $4 \mathrm{H}, J=8.6 \mathrm{~Hz}), 7.03(\mathrm{~d}, 2 \mathrm{H}, J=8.8 \mathrm{~Hz})$.

4-(Dibiphenyl-4-ylamino)phenylboronic Acid (3c): $\mathrm{N}$ (Biphenyl-4-yl)- $N$-(4-bromophenyl) biphenyl-4-amine (4.75 $\mathrm{g}, 10 \mathrm{mmol}$ ) was dissolved at $100 \mathrm{~mL}$ THF in $250 \mathrm{~mL}$ round 
bottom flask. $n$-BuLi ( $10 \mathrm{~mL}, 20 \mathrm{mmol})$ was slowly added to the reaction mixture at $-78^{\circ} \mathrm{C}$ and kept the temperature for 2 h. After triisopropylborate $(10 \mathrm{~mL}, 40 \mathrm{mmol})$ was slowly added to the lithated solution, the resulting mixture was slowly raised to room temperature and kept stirring for $12 \mathrm{~h}$. The reaction mixture was acidified with $2 \mathrm{~N} \mathrm{HCl}$ until $\mathrm{pH} 6$. The product was extracted with ethyl acetate. The ethyl acetate was dried with $\mathrm{MgSO}_{4}$, filtered, and concentrated. The product $(3.5 \mathrm{~g}, 83 \%)$ was obtained as white solid by recrystallization with hexane. $\mathrm{mp} 234-237{ }^{\circ} \mathrm{C}$; ${ }^{1} \mathrm{H}$ NMR $(400$ $\left.\mathrm{MHz}, \mathrm{CDCl}_{3}\right) \delta 7.89(\mathrm{~s}, 2 \mathrm{H}), 7.89(\mathrm{~s}, 2 \mathrm{H}), 7.65(\mathrm{~m}, 11 \mathrm{H})$, $7.74(\mathrm{t}, 4 \mathrm{H}, J=7.7 \mathrm{~Hz}), 7.40(\mathrm{t}, 2 \mathrm{H}, J=8.8 \mathrm{~Hz}), 7.35(\mathrm{t}, 4 \mathrm{H}$, $J=7.7 \mathrm{~Hz}), 7.05(\mathrm{~m}, 5 \mathrm{H})$.

7-Bromo-9-phenyl-9H-carbazole-3-carbaldehyde (3d): 2-Bromo-9-phenyl-9H-carbazole (321 mg, $1 \mathrm{mmol}$ ), $\mathrm{POCl}_{3}$ (0.7 mL, $10 \mathrm{mmol})$, and DMF $(0.8 \mathrm{~mL}, 10 \mathrm{mmol})$ were dissolved $15 \mathrm{~mL}$ of chlorobenzene under $\mathrm{N}_{2}$ gas. The resulting solution was stirred at $80^{\circ} \mathrm{C}$ for $48 \mathrm{~h}$ under $\mathrm{N}_{2}$ gas. After completed reaction, the reaction mixture was neutralized with sodium carbonate. The product was extracted with ethyl acetate. The ethyl acetate layer was dried with $\mathrm{MgSO}_{4}$, filtered, and concentrated. The product (200 mg, 61\%) was obtained as white solid by column chromatograpy with hexane:MC = 20:1. mp 180-182 ${ }^{\circ} \mathrm{C} ;{ }^{1} \mathrm{H}$ NMR (400 MHz, $\left.\mathrm{CDCl}_{3}\right) \delta 10.08(\mathrm{~s}, 1 \mathrm{H}), 8.55(\mathrm{~s}, 1 \mathrm{H}), 7.97(\mathrm{~m}, 2 \mathrm{H}), 7.53(\mathrm{~m}$, $6 \mathrm{H}), 7.45(\mathrm{~m}, 2 \mathrm{H})$.

7-(4-(Dibiphenyl-4-ylamino)phenyl)-9-phenyl-9H-carbazole-3-carbaldehyde (3e): 7-Bromo-9-phenyl-9H-carbazole3-carbaldehyde (350 mg, $1 \mathrm{mmol}$ ), 4-(dibiphenyl-4-ylamino)phenylboronic acid (610 mg, $1.5 \mathrm{mmol}), \mathrm{Pd}\left(\mathrm{Ph}_{3}\right)_{4}(40$ $\mathrm{mg}, 0.04 \mathrm{mmol})$, and $\mathrm{K}_{2} \mathrm{CO}_{3}(416 \mathrm{mg}, 4 \mathrm{mmol})$ were dissolved at $12 \mathrm{~mL}$ of mixed solvent (Toluene:THF: $\mathrm{H}_{2} \mathrm{O}=$ $5: 5: 2)$ in pressure bottle. The reaction mixture was stirred at $80{ }^{\circ} \mathrm{C}$ for $2 \mathrm{~h}$. The product was extracted with ethyl acetatewater. The ethyl acetate layer was dried with $\mathrm{MgSO}_{4}$, filtered, and concentrated. The product (600 mg, 60\%) was obtained as white solid by column chromatograpy with hexane:MC = 7:1. mp 211-213 ${ }^{\circ} \mathrm{C} ;{ }^{1} \mathrm{H}$ NMR $(400 \mathrm{MHz}$, $\left.\mathrm{CDCl}_{3}\right) \delta 10.12(\mathrm{~s}, 1 \mathrm{H}), 8.67(\mathrm{~s}, 1 \mathrm{H}), 8.22(\mathrm{~d}, 1 \mathrm{H}, J=8 \mathrm{~Hz})$, 7.95 (dd, 1H, $J=8,1.2 \mathrm{~Hz}), 7.6(\mathrm{~m}, 19 \mathrm{H}), 7.47$ (m, 11H).

$\mathrm{N}$-(Biphenyl-4-yl)- $\mathrm{N}$-[4-(9-phenyl-6-vinyl-9H-carbazol2-yl) phenyl]biphenyl-4-amine (3f): Methyltriphenylphosphonium bromide (2 g, $5.8 \mathrm{mmol}$ ) was dissolved at $40 \mathrm{~mL}$ THF in $100 \mathrm{~mL}$ round bottom flask under $\mathrm{N}_{2}$ gas. $1.6 \mathrm{M}$ solution of $n$-BuLi (3.6 mL, $5.28 \mathrm{mmol})$ was slowly added to the reaction mixture at $-78^{\circ} \mathrm{C}$. The reaction mixture was raised until room temperature and stirred for $1 \mathrm{~h}$ at room temperature. 7-(4-(Dibiphenyl-4-ylamino)phenyl)-9-phenyl$9 \mathrm{H}$-carbazole-3-carbaldehyde (3 $\mathrm{g}, 4.8 \mathrm{mmol})$ was added to the litiated solution at $-78{ }^{\circ} \mathrm{C}$. The reaction mixture was stirred for $2 \mathrm{~h}$ at $-78{ }^{\circ} \mathrm{C}$. The reaction product was extracted with ethyl acetate-water. The ethyl acetate was dried with $\mathrm{MgSO}_{4}$, filtered, and concentrated. The product $(2.4 \mathrm{~g}, 80 \%)$ was obtained as white solid by column chromatograpy with hexane:MC = 8:1. mp 145-147 ${ }^{\circ} \mathrm{C}$; ${ }^{1} \mathrm{H}$ NMR $(400 \mathrm{MHz}$, $\left.\mathrm{CDCl}_{3}\right) \delta 8.17(\mathrm{~d}, 1 \mathrm{H}, J=8 \mathrm{~Hz}), 7.50(\mathrm{~m}, 24 \mathrm{H}), 7.29(\mathrm{~m}$, $8 \mathrm{H}), 6.92(\mathrm{dd}, 1 \mathrm{H}, J=17.2 \mathrm{~Hz}), 5.79(\mathrm{~d}, 1 \mathrm{H}, J=18 \mathrm{~Hz})$, $5.23(\mathrm{~d}, 1 \mathrm{H}, J=10.8 \mathrm{~Hz})$.

Acknowledgments. This work was financially supported by the research fund of Chungnam National University (2010-1626).

\section{References}

1. Katritziky, A. R.; Rees, C. W.; Scriven, E. F. V. Comprehensive Heterocyclic Chemistry II 1996, 2, 207-257 and references therein.

2. Knolker, H.-J. Topics in Current Chemistry 2005, 244, 115 and references therein.

3. Bubniene, G.; Malinauskas, T.; Daskeviciene, M.; Jankauskas, V.; Getautis, V. Tetrahedron 2010, 66, 3199 and reference therein.

4. Wong, W.-Y.; Ho, C.-L.; Gao, Z.-Q.; Mi, B.-X.; Chen, C.-H.; Cheah, K.-W.; Lin, Z. Angew. Chem. Int. Ed. 2006, 45, 7800. (b) Zhang, K.; Chen, Z.; Yang, C.; Zhang, X.; Tao, Y.; Duan, L.; Chen, L.; Zhu, L.; Qin, J.; Cao, Y. J. Mater. Chem. 2007, 17, 3451. (c) Zhang, X.; Chen, Z.; Yang, C.; Li, Z.; Zhang, K.; Yao, H.; Qin, J.; Chen, J.; Cao, Y. Chem. Phys. Lett. 2006, 422, 386. (d) Ho, C.-L.; Wang, Q.; Lam, C.-S.; Wong, W.-Y.; Ma, D.; Wang, L.; Gao, Z.-Q.; Chen, C.H.; Cheah, K.-W.; Lim, Z. Chem. Asian. J. 2009, 4, 89.

5. (a) Baeupre, S.; Boudreault, P.-L. T.; Leclerc, M. Adv. Mater. 2010, 22, E6-27. (b) Shen, J.-Y.; Yang, X.-L.; Huang, T.-H.; Lin, J. T.; Ke, T.-H.; Chen, L.-Y.; Wu, C.-C.; Yeh, M.-C. P. Adv. Funct. Mater. 2007, 17, 983. (c) Chauhan, S. S.; Yi, H.; Iraqi, A. Mol. Cryst. Liq. Crys. 2008, 497, 129.

6. (a) Li, J.; Grimsdale, A. C. Chem. Soc. Rev. 2010, 39, 2399 and references therein. (b) Kim, D.; Lee, J. K.; Kang, S. O.; Ko, J. J. Tetrahedron 2007, 63, 1913.

7. Bellina, F.; Calandri, C.; Cauteruccio, S.; Ross, R. Eur. J. Org Chem. 2007, 2147.

8. (a) Wong, K.-T.; Ku, S.-Y.; Yen, F.-W. Tetrahedron Lett. 2007, 48, 5051. (b) Hosseinzadeh, R.; Tajbakhsh, M.; Alikarami, M.; Mohadjerani, M. J. Heterocyclic Chem. 2008, 45, 1815. (c) Xi, Z.; Liu, F.; Zhou, Y.; Chen, W. Tetrahedron 2008, 64, 4254.

9. (a) Larock, R. C.; Yum, E. K. J. Am. Chem. Soc. 1991, 113, 6689. (b) Larock, R. C.; Yum, E. K.; Refvik, M. D. J. Org. Chem. 1998, 63, 7652. (c) Hong, K. B.; Lee, C. W.; Yum, E. K. Tetrahderon Lett. 2004, 45, 693.

10. (a) Park, S. S.; Choi, J.-K.; Yum, E. K.; Ha, D.-C. Tetrahedron Lett. 1998, 39, 627. (b) Chi, S. M.; Choi, J.-K.; Yum, E. K.; Chi, D. Y. Tetrahedron Lett. 2000, 41, 919. (c) Lee, M. S.; Yum, E. K. Bull. Korean Chem. Soc. 2002, 23, 535. (d) Kang, S. S.; Yum, E. K.; Sung, N. D. Heterocycles 2003, 60, 2727. (e) Hong, C. S.; Seo, J. Y.; Yum, E. K.; Sung, N.-D. Heterocycles 2004, 63, 631. (f) Hong, C. S.; Seo, J. Y.; Yum, E. K. Tetrahedron Lett. 2007, 48, 4831.

11. (a) Kang, S. K.; Park, S. S.; Kim, S. S.; Choi, J.-K.; Yum, E. K. Tetrahedron Lett. 1999, 40, 4379. (b) Yum, E. K.; Kang, S. K.; Kim, S. S.; Choi, J.-K.; Cheon, H. G. Bioorg. Med. Chem. Lett. 1999, 9, 1819. (c) Lee, W. J.; Gee, M. B.; Yum, E. K. Heterocycles 2003, 60, 1821.

12. (a) Freeman, A. W.; Urovoy, M.; Criswell, M. E. J. Org. Chem. 2005, 70, 5014. (b) Dierschke, F.; Grimsdale, A. C.; Mullen, K. Synthesis 2003, 2470.

13. Barton, N.; Fabre-Franch, I.; Bourrat, D.; Chanbezen, F.; Sadki, S. J. Phys. Chem. 2009, 113, 14087.

14. Li, J.; Mark, J. J. Chem. Mater. 2008, 20, 4873.

15. Low, P. J.; Paterson, M. J.; Yufit, D. S.; Howward, J. A. K.; Cherryman, J. C.; Tackley, D. R.; Brrok, R.; Brown, B. J. Mater. Chem. 2005, 15, 2304.

16. Ma, B.; Lauterwasser, F.; Deng, L.; Zonte, S.; Kim, B. J.; Frechet, J. M. J. Chem. Mater. 2007, 19, 4827.

17. Kitawaki, T.; Hayashi, Y.; Ueno, A.; Chida, N. Tetrahedron 2006, 62,6792 .

18. Kwon, J. K.; Cho, J. H.; Ryu, Y.-S.; Oh, S. H.; Yum, E. K. Tetrahedron 2011, 67, 4820 . 